\title{
Removal of Escherichia coli from Domestic Wastewater Using Electrocoagulation
}

\author{
Edwar Aguilar-Ascon ${ }^{1}$ \\ 1 Universidad de Lima, Av. Javier Prado, 4600 Surco, Lima, e-mail: eaguilaa@ulima.edu.pe
}

\begin{abstract}
The objective of this study was to evaluate the efficiency of electrocoagulation in the removal of Escherichia coli from domestic and urban wastewaters and to determine the effects of the main operational parameters on the process. An electrocoagulation reactor with aluminum and iron electrodes was built for this purpose. A factorial design was applied, where amperage, treatment time, and $\mathrm{pH}$ were considered as the factors and E. coli percent removal was the response variable. After $20 \mathrm{~min}$ of treatment, $>97 \%$ removal efficiency was achieved. The highest E. coli removal efficiency achieved was $99.9 \%$ at a neutral $\mathrm{pH}$ of 7 , amperage of $3 \mathrm{~A}$, and treatment time of 60 min. However, the removal efficiency of close to $99 \%$ was also achieved at natural wastewater $\mathrm{pH}$ of 8.5 . The statistical analyses showed that the three tested factors significantly affected the E. coli removal percentage $(p<0.05)$. These results indicate that electrocoagulation has a high disinfection power in a primary reactor in removing water contaminants as well as simultaneously removing pathogenic microorganisms when compared to biological treatment processes. This represents an additional benefit, because it will considerably reduce the use of chlorine during the final disinfection stage.
\end{abstract}

Keywords: domestic wastewater, electrocoagulation, escherichia coli, electrochemical disinfection

\section{INTRODUCTION}

The primary objective of most traditional drinking and wastewater treatment plants in Peru is to remove organic matter and different contaminants. However, they are not very efficient in the disinfection process, that is, in the removal of pathogenic microorganisms. An additional disinfection process is therefore required to remove pathogens. The addition of chlorine is the most commonly used method worldwide, employed in approximately $90 \%$ of water treatment plants [Silva, 2015], owing to its simplicity, low cost, and high efficiency. Chlorine is an important biocidal agent; however, it is not properly used and, in some cases, it is overused. When added to water, chlorine, in its different forms, reacts with the naturally occurring organic substances, generating by-products, such as trihalomethanes (THMs). These compounds reportedly cause various diseases, including cancer [Silva, 2015]. The use of chlorine is prohibited in such countries as Germany, and there are various governing regulations in Spain [Guillemes, 2015]; however, it is widely used in Peru. Moreover, such chemicals become less effective over time; that is, they have a limited storage time and, as such, cannot be stored in large volumes, thereby increasing the logistics costs [Guillemes, 2015].

Novel disinfection methods that do not require chlorine, such as UV irradiation, ozonation, and electrocoagulation or electrochemical disinfection, have been studied over the last few years. Electrocoagulation generates a wide range of oxidizers, such as hydrogen peroxide and ozone, in the presence of oxygen molecules as well as free chlorine and chlorine dioxide in the presence of chloride ions [Ricordel, 2014].

Electrocoagulation involves the generation of coagulants in the sacrificial anode, usually made of aluminum or iron [Holt et al., 2005], as a result of the continuous electrical current supply [Can O.T., 2014], which enables the agglomeration of colloidal particles that are removed by flotation or precipitation [Piña et al., 2011]. Metallic cations such as $\mathrm{Al}^{3+}$ and $\mathrm{Fe}^{2+}$ are produced in situ in 
the anode and therefore do not need to be externally supplied (Figure 1). Simultaneously, gases, mainly hydrogen, which make the coagulated contaminant float to the surface, are produced in the cathode [Holt et al., 2005]. Numerous electrochemical reactions occur during electrocoagulation (equation 1) [Mouedhen et al., 2008; Chen 2004].

In the anode:

$$
A l \rightarrow A l^{3+}+3 e
$$

In the cathode:

$$
3 \mathrm{H}_{2} \mathrm{O}+3 e \rightarrow \frac{3}{2} \mathrm{H}_{2}(g)+3 \mathrm{OH}^{-}
$$

In the solution:

$$
\mathrm{Al}^{3+}(a q)+3 \mathrm{H}_{2} \mathrm{O} \rightarrow \mathrm{Al}(\mathrm{OH})_{3}+3 \mathrm{H}^{+}(a q)
$$

During the electrocoagulation process an electric field is generated around different contaminants and microorganisms present in water.
Several authors have theoretically explained the effects of an electric field on bacteria in terms of membrane permeability and stability, and this electric field could rupture the cellular membrane [Zimmermann, 1973; Boudjema, 2014]. Some studies report electrochemical inactivation of bacterial and yeast cells. In the case of fecal coliforms such as Escherichia coli, an increase in the distance between the inner and outer membranes is seen during polarization and rupture. The microorganism inactivation rate increases along with amperage, while effectiveness increases with treatment time [Zimmermann, 1973; Boudjema, 2014].

In 2008, Ghernaout applied this process for the disinfection of artificial wastewaters contaminated with strains of $E$. coli. The results indicate that aluminum electrodes are the most efficient in destroying E. coli cells in comparison with stainless steel and carbon steel electrodes. In 2013, Ricordel investigated the effect of aluminum electrodes on model solutions with $E$. coli cultures, achieving 97\% reduction after $35 \mathrm{~min}$ at an amperage of $0.22 \mathrm{~A}$. In 2014, Boudjema

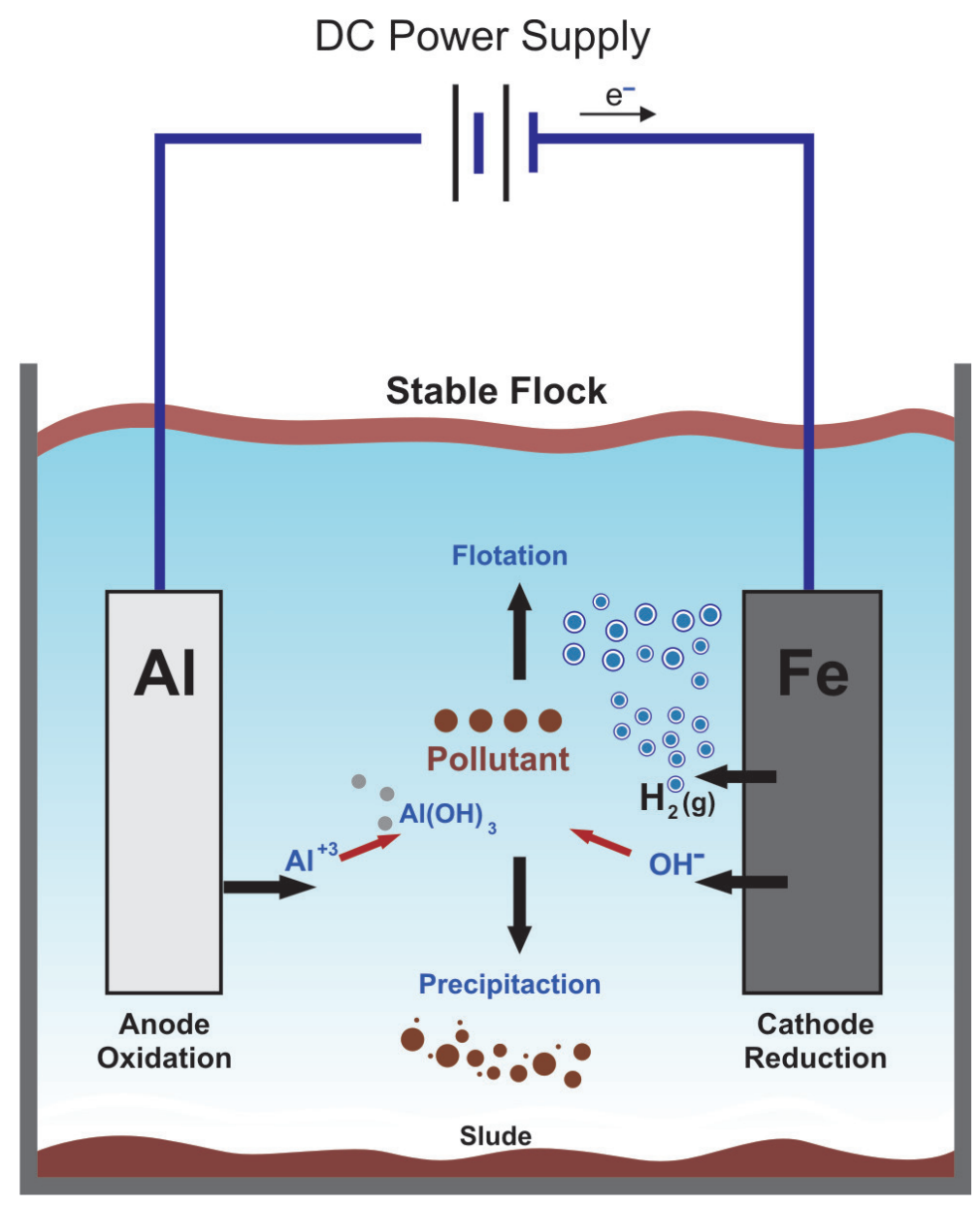

Figure 1. Reactions from the electrocoagulation process 
applied electrocoagulation using aluminum electrodes to remove fecal coliforms from river water and achieved $99 \%$ reduction of these parameters. Taking into consideration the problem presented, it is of utmost importance to search for alternatives for disinfection, and in this particular case, to eliminate pathogenic microorganisms such as E. coli. Because only few studies have applied the electrocoagulation process to domestic and urban wastewaters, this study aimed at providing results using real conditions for the removal of $E$. coli using electrocoagulation.

To this end, the main objective of this study was to evaluate the efficiency of electrocoagulation on the removal of $E$. coli from domestic and urban wastewaters and to determine how the main parameters of the process (amperage, treatment time, and $\mathrm{pH}$ ) affect it.

\section{MATERIALS AND METHODS}

\section{Wastewater used}

Domestic wastewater was obtained from a treatment plant at the Wastewater and Hazardous Residues Research Center of the National Engineering University (Citrar-UNI), which receives the domestic effluents from an urban zone of the city of Lima.

\section{Electrocoagulation reactor}

A batch-type laboratory-scale electrocoagulation reactor with a capacity of $10 \mathrm{~L}$ of water was fabricated using transparent acrylic. Four aluminum plates were used as sacrificial electrodes in the anode, and four $0.01-\mathrm{cm}$ thick, $10-\mathrm{cm}$ wide, and $10-\mathrm{cm}$ long iron plates were used in the cathode, resulting in an area of $100 \mathrm{~cm}^{2}$ (Fig. 2).
A power source capable of supplying 0-15 A and adjustable voltage of $0-32 \mathrm{~V}$ was used to supply electrical current.

\section{Experimental trials}

The experimental design included three types of trials, maintaining the natural $\mathrm{pH}$ of the water and then modifying it towards a neutral value. In all of these trials, amperage was manipulated, and samples were collected at 10 -min intervals until $60 \mathrm{~min}$ of treatment. The measurements of $\mathrm{pH}$, conductivity, and temperature were taken in the field with using Oakton PCS 35 multiparameter device. The samples to determine the E. coli concentration were stored, labeled, and sent to the laboratory for analysis. The analysis method in "SMEWW-APHAAWWA-WEF, Part9221B, C, E, G.2012; 22nd Ed. Other Escherichia coli Procedures" was used to determine the E. coli concentration in the raw and treated samples. Equation 4 was used to calculate the percent removal.

For E. coli:

$$
\% \mathrm{R}=\left(\frac{\text { Ecoli }_{i}-\text { Ecoli }_{\mathrm{f}}}{\text { Ecoli }_{i}}\right) \times 100
$$

where:

$\% \mathrm{R}-$ E.coli percent removal,

E.coli - Initial Escherichia coli concentration,

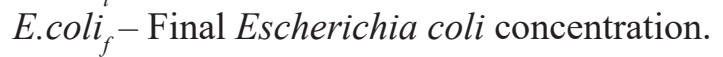

\section{Experimental design}

A fully randomized three-factor factorial design with varying values was used. The factors considered in the design were amperage $\left(\mathrm{x}_{1}\right)$, treatment time $\left(\mathrm{x}_{2}\right)$, and $\mathrm{pH}\left(\mathrm{x}_{3}\right)$, while the E. coli percent removal was the response variable $\left(\mathrm{y}_{1}\right)$

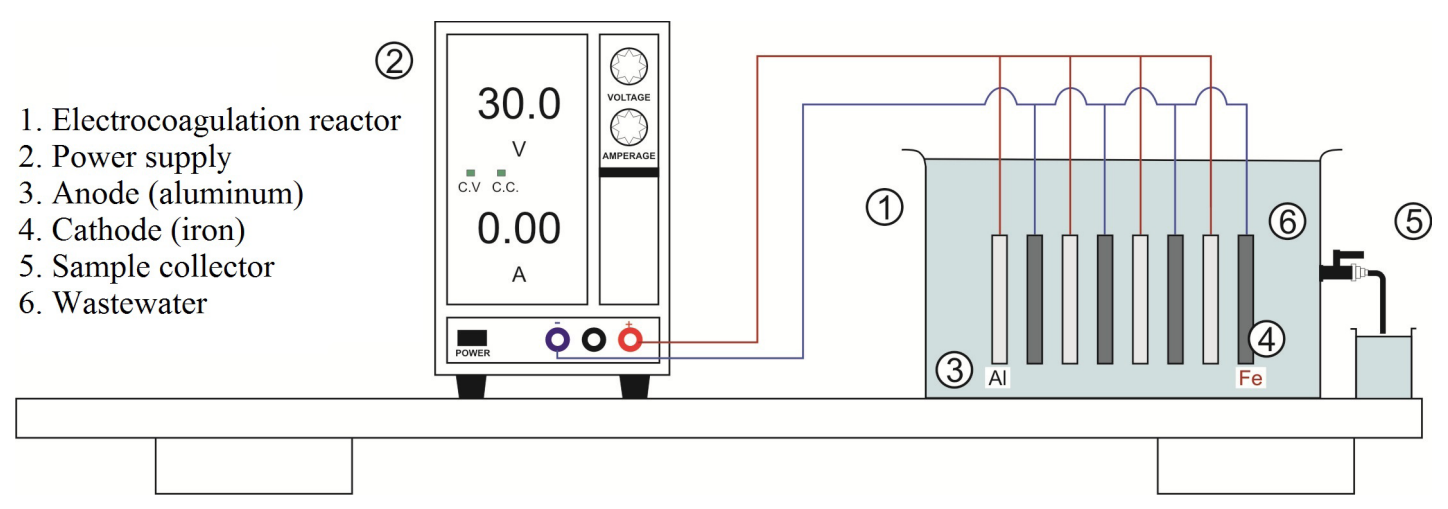

Figure 2. Diagram of the electrocoagulation reactor 
(Table 1). This enabled us to determine the individual and interaction effects of the factors on the response variable and to identify how significant they were in the process. The statistical analyses were performed using Statgraphics Centurion XVI software and included an analysis of variance (ANOVA table) with a confidence level of $95 \%(\mathrm{p}<0.05)$, regression coefficients of a generalized second-order polynomial, and response surface figures. The model used for the analysis is detailed in equation 5 .

$$
\begin{aligned}
y_{i}= & b_{0}+\sum_{i=1}^{n} b_{i} x_{i}+\sum_{i=1}^{n} b_{i i} x_{i}{ }^{2}+ \\
& +\sum_{i=1}^{n-1} \sum_{j=i+1}^{n} b_{i j} x_{i} x_{j}
\end{aligned}
$$

Where $b_{0}, b_{i}, b_{i i}$ and $b_{i j}$ are the coefficients for linear, quadratic, and second-order interaction, respectively. Moreover, $\mathrm{x}_{\mathrm{i}}$ and $\mathrm{x}_{\mathrm{j}}$ represent the values for the independent variable, and $y_{i}$ represents the $E$. coli percent removal. The fit of the polynomial model was expressed using the regression coefficient $\mathrm{R}^{2}$.

Table 1. Physicochemical and microbiological analyses of domestic wastewater

\begin{tabular}{|l|c|}
\hline \multicolumn{1}{|c|}{ Parameter } & Value \\
\hline Total coliforms (MPN/100 ml) & 92000000 \\
\hline Fecal coliforms (MPN/100 ml) & 16000000 \\
\hline Escherichia coli $(\mathrm{MPN} / 100 \mathrm{ml})$ & 2400000 \\
\hline $\mathrm{pH}$ & 8.5 \\
\hline Conductivity $(\mu \mathrm{S} / \mathrm{cm})$ & 1200 \\
\hline COD $(\mathrm{mg} / \mathrm{L})$ & 390.9 \\
\hline BOD ${ }_{5}(\mathrm{mg} / \mathrm{L})$ & 137.0 \\
\hline Total solids $(\mathrm{mg} / \mathrm{L})$ & 113 \\
\hline Oils and fats $(\mathrm{NTU})$ & 27.1 \\
\hline Total nitrogen $(\mathrm{mg} / \mathrm{L})$ & 5.29 \\
\hline Total phosphorous $(\mathrm{mg} / \mathrm{L})$ & 4.820 \\
\hline
\end{tabular}

\section{RESULTS AND DISCUSSION}

Table 2 presents the results of this study, which shows the concentration of $E$. coli as 2400000 (MPN/100 ml). On the other hand, the values of BOD and COD were $137 \mathrm{mg} / \mathrm{L}$ and $390.9 \mathrm{mg} / \mathrm{L}$, respectively, while conductivity and $\mathrm{pH}$ had acceptable values to use the electrocoagulation process.
Table 2. Experimental design factors and levels for Escherichia coli

\begin{tabular}{|l|c|c|c|c|c|c|}
\hline \multicolumn{1}{|c|}{ Factors } & \multicolumn{5}{c|}{ Values } \\
\hline$x_{1}:$ Amperage (A) & \multicolumn{2}{|c|}{1} & \multicolumn{2}{c|}{2} & \multicolumn{2}{c|}{3} \\
\hline$x_{2}:$ Time $(\min )$ & 10 & 20 & 30 & 40 & 50 & 60 \\
\hline$x_{3}: \mathrm{pH}$ & \multicolumn{3}{|c|}{7} & \multicolumn{3}{c|}{8.5} \\
\hline
\end{tabular}

\section{Effect of amperage}

Amperage, also expressed as current density, which is defined as the relation between the current and the electrode surface, is a key parameter in the electrocoagulation process. Amperage determines the coagulant dosing at the anode and the formation of hydrogen gas in the cathode, as a consequence of Faraday's Law [Holt, 2005; Hakizimana, 2017]. The bubble density affects the system hydrodynamics, which in turn influences the mass transfer among contaminants, coagulant, and gas microbubbles, and finally dictates the collision rate of coagulated particles, which results in the formation of flocs [Hakizimana, 2017]. An increase in amperage accelerates the electrocoagulation process, particularly at the beginning [Attour et al., 2014]. (Fig. 3 and 5 ) illustrate an increase in the removal of microorganism with increasing amperage, although it is not substantial. After $30 \mathrm{~min}$ of treatment, at all three amperage values, 99\% removal efficiency was achieved. Figures 4 and 6 show that the best results were obtained at the amperage values of $2 \mathrm{~A}$ and $3 \mathrm{~A}$, following $60 \mathrm{~min}$ of treatment, wherein the E. coli concentration decreased from 2400000 (MPN/100 ml) to 9200 (MPN/100 $\mathrm{ml}$ ), thereby achieving up to $99.9 \%$ removal efficiency. These results match those reported by Gusmao in 2010, who indicated that a treatment time of 60 min could eliminate $98.8 \%$ of E. coli. Moreover, in 2015, Castro indicated that a 1-log E. coli removal from lab-prepared synthetic water can be achieved after $40 \mathrm{~min}$ of treatment. This removal is attributed to the adsorption of E. coli on the flocs formed by the electrocoagulation process, which rise to the surface or precipitate to the bottom of the reactor due to flotation [Ghernaout et al., 2008]. The high removal efficiencies found are also extremely similar to those obtained by Ricordel, who reported 97\% removal efficiency, where the removal of bacteria using electrocoagulation could be attributed to strong bacterial adhesion on the surface of aluminum-electrogenerated particles, followed by the separation of the precipitated solids. Conversely, in 2014, Chopra 


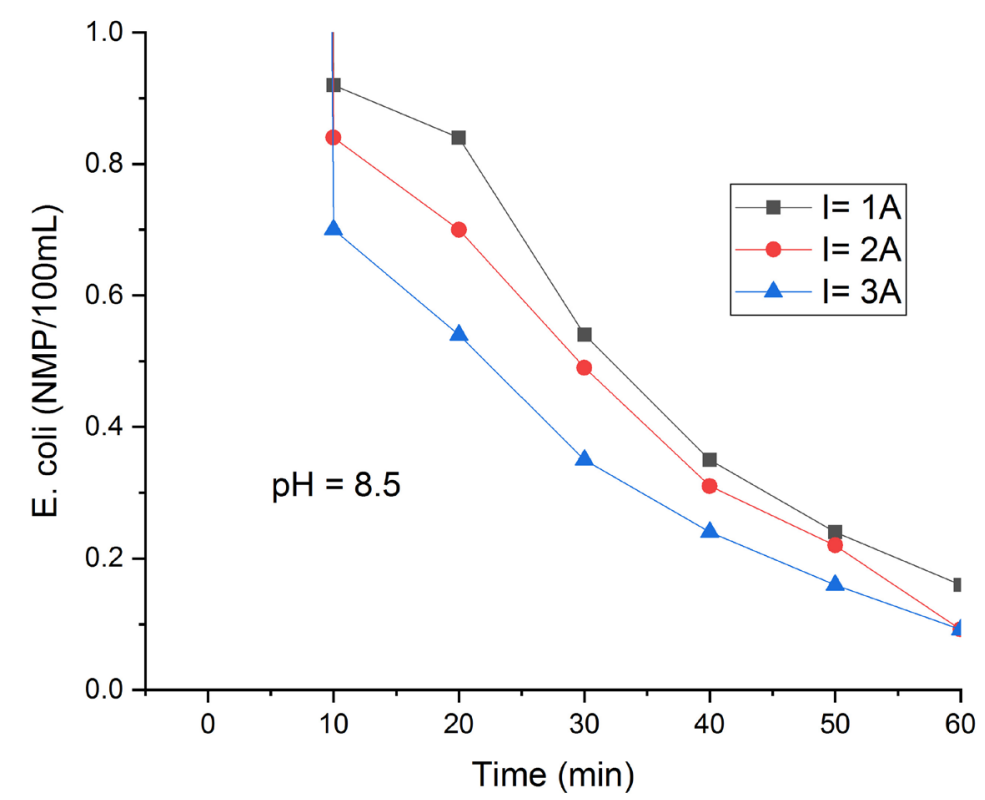

Figure 3. Escherichia coli variation as a function of time at different amperage values (E. $\operatorname{coli}=2400000 \mathrm{MPN} / 100 \mathrm{ml} ; \mathrm{pH}=8.5$ )

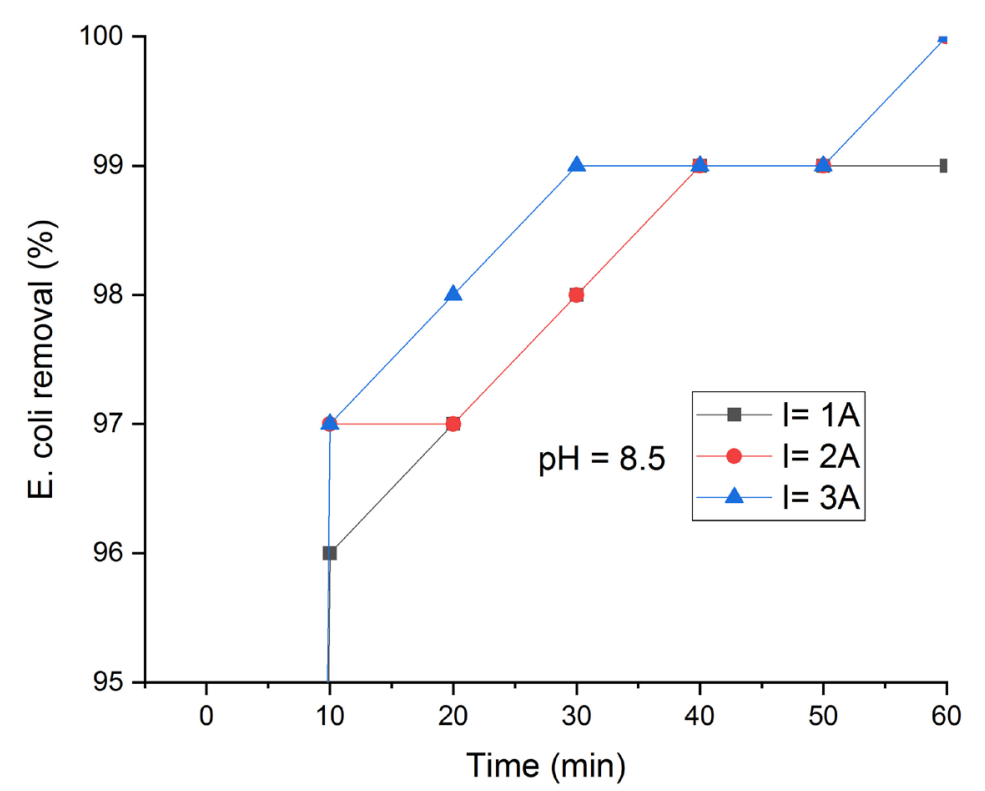

Figure 4. Escherichia coli percent removal as a function of time (E. coli $=2400000 \mathrm{MPN} / 100 \mathrm{ml} ; \mathrm{pH}=8.5)$

reported high pathogenic microorganism removal considering total coliforms, achieving $99.9 \%$ removal efficiency after $40 \mathrm{~min}$ of treatment at a current density of $2.65 \mathrm{~A} / \mathrm{m}^{2}$.

\section{Effect of treatment time}

With increasing treatment time, the concentration of metallic ions and their hydroxide flocs grows as well [Chopra, 2014], allowing for better contaminant coagulation and flocculation. As a result, the contaminant removal efficiency increases along with retention time, up to a point where this efficiency becomes constant [Khandegar, 2013]. (Fig. 3, 4, 5, and 6) illustrate a high pathogenic microorganism removal within the first $10 \mathrm{~min}$ of treatment, reaching $97 \%$ owing to the removal of a large quantity of organic matter and flocs. After 30 min of treatment, $99 \%$ removal efficiency was achieved both at natural as well as neutral $\mathrm{pH}$ values, and it became almost constant up to $60 \mathrm{~min}$ of treatment. Treatment time is faster with higher current density; these two parameters are closely connected [Attour et al., 2014]. 


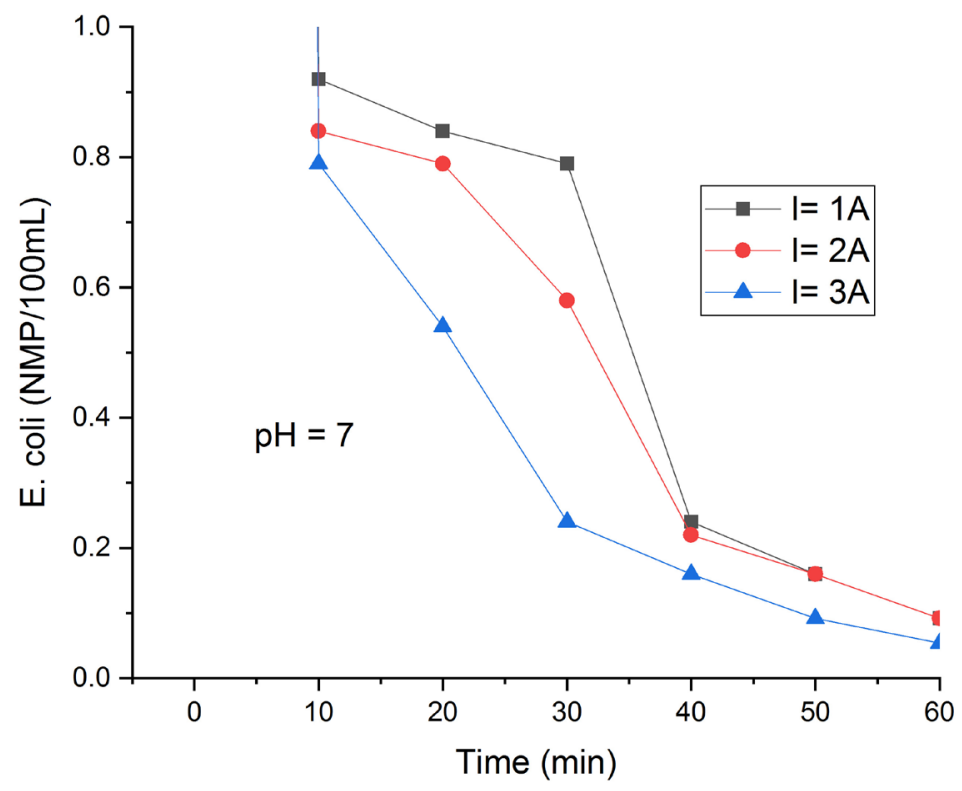

Figure 5. Escherichia coli variation as a function of amperage values (E. coli $=2400000 \mathrm{MPN} / 100 \mathrm{ml} ; \mathrm{pH}=7$ )

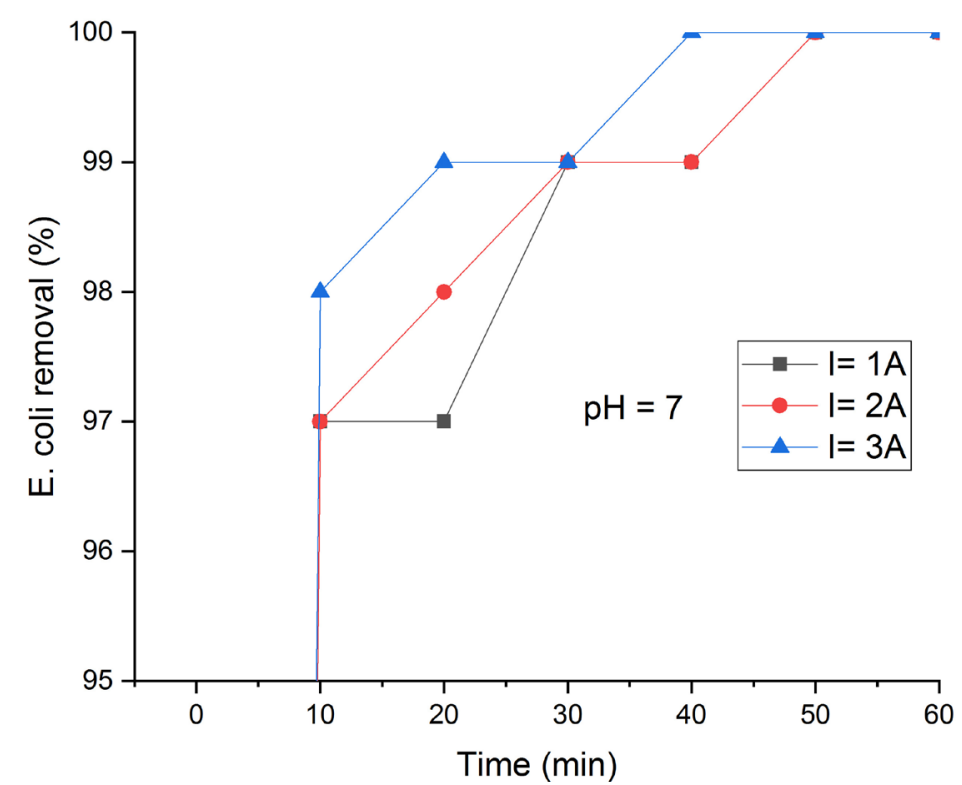

Figure 6. Escherichia coli percent removal as a function of time $($ E. coli $=2400000 \mathrm{MPN} / 100 \mathrm{ml} ; \mathrm{pH}=7)$

\section{Effect of $\mathrm{pH}$}

The initial $\mathrm{pH}$ of wastewater is one of the most important factors affecting the efficiency of electrocoagulation [Can, 2014; Bouamra et al., 2012]. The solubility of metallic hydroxides [Mollah, 2004], which act as coagulants, enabling the agglomeration of colloidal particles, also affects the efficiency of electrocoagulation [Piña et al., 2011]. For aluminum, the predominant forms are $\mathrm{Al}^{3+}$ cations at low $\mathrm{pH}, \mathrm{Al}(\mathrm{OH})_{4}^{-}$aluminates at $\mathrm{pH} \geq 10$, and non-soluble hydroxides $\mathrm{Al}(\mathrm{OH})_{3}$ at an intermediate or neutral pH [Yehya et al., 2014]. The highest $E$. coli percent removal reached $99.9 \%$ at a neutral $\mathrm{pH}$ of 7 , amperage of $3 \mathrm{~A}$, and treatment time of 60 min (Fig. 5 and 6). However, a similar efficiency of $99 \%$ was obtained at the natural $\mathrm{pH}$ of water $(\mathrm{pH} 8.5)$. These results are consistent with those reported by Chopra in 2014, who indicated achieving the best efficiency at a close to neutral pH of 7.5. In 2013, Ricordel analyzed the effect of $\mathrm{pH}$ on the E. coli removal efficiency and pointed out that when the initial $\mathrm{pH}$ increased from 7.5 to 9.5, E. coli removal efficiency 
significantly decreased from $96 \%$ to $72 \%$ in an average time of $35 \mathrm{~min}$ and an amperage of 0.22 A. The best removal efficiency was achieved at the $\mathrm{pH}$ values close to 7 .

\section{Experimental design results}

According to the proposed experimental design, Table 3 illustrates the 36 experiments conducted in this study. Moreover, equation 5 presents the quadratic regression model for $E$. coli percent removal $\left(\mathrm{y}_{1}\right)$, which enables us to investigate the effects of the independent variables $\left(\mathrm{x}_{1}, \mathrm{x}_{2}\right.$, and $\left.\mathrm{x}_{3}\right)$ and their effect on the response variable $\left(\mathrm{y}_{1}\right)$.

$$
\begin{aligned}
& Y_{(1)}=98.452+0.35 x_{1}+0.117024 x_{2}- \\
& -0.474074 x_{3}+0.0833333 x_{1}^{2}-0.01 x_{1} x_{2}+ \\
& +0.0 x_{1} x_{3}-0.00077381 x_{2}^{2}+0.00190476 x_{2} x_{3}
\end{aligned}
$$

ANOVA showed a regression coefficient $\left(\mathrm{R}^{2}\right)$ of 0.9287 for $E$. coli, which means that the proposed statistical model explains $92.87 \%$ of the variation in $E$. coli percent removal and indicates a good model fit (Table 4).

Figure 7 illustrates the main effects on the response variable, with the effect of time, amperage, and $\mathrm{pH}$ being significant at a significance

\begin{tabular}{|c|c|c|c|c|c|c|c|c|c|}
\hline \multirow{3}{*}{ Exp. $\mathrm{N}^{\circ}$} & \multicolumn{4}{|c|}{ Factors } & \multirow{3}{*}{ Exp. $\mathrm{N}^{\circ}$} & \multicolumn{4}{|c|}{ Factors } \\
\hline & $\begin{array}{l}\text { Amperage } \\
\text { (A) }\end{array}$ & $\begin{array}{l}\text { Time } \\
(\min )\end{array}$ & $\mathrm{pH}$ & $\begin{array}{l}\text { E. coli } \\
\text { percent } \\
\text { removal }\end{array}$ & & $\begin{array}{c}\text { Amperage } \\
\text { (A) }\end{array}$ & $\begin{array}{l}\text { Time } \\
(\min )\end{array}$ & $\mathrm{pH}$ & $\begin{array}{l}\text { E. coli percent } \\
\text { removal }\end{array}$ \\
\hline & $x_{1}$ & $x_{2}$ & $x_{3}$ & $y$ & & $x_{1}$ & $x_{2}$ & $x_{3}$ & $y$ \\
\hline 1 & 1 & 10 & 7 & 97 & 19 & 2 & 10 & 8.5 & 97 \\
\hline 2 & 1 & 20 & 7 & 97 & 20 & 2 & 20 & 8.5 & 97 \\
\hline 3 & 1 & 30 & 7 & 99 & 21 & 2 & 30 & 8.5 & 98 \\
\hline 4 & 1 & 40 & 7 & 99 & 22 & 2 & 40 & 8.5 & 99 \\
\hline 5 & 1 & 50 & 7 & 100 & 23 & 2 & 50 & 8.5 & 99 \\
\hline 6 & 1 & 60 & 7 & 100 & 24 & 2 & 60 & 8.5 & 100 \\
\hline 7 & 1 & 10 & 8.5 & 96 & 25 & 3 & 10 & 7 & 98 \\
\hline 8 & 1 & 20 & 8.5 & 97 & 26 & 3 & 20 & 7 & 99 \\
\hline 9 & 1 & 30 & 8.5 & 98 & 27 & 3 & 30 & 7 & 99 \\
\hline 10 & 1 & 40 & 8.5 & 99 & 28 & 3 & 40 & 7 & 100 \\
\hline 11 & 1 & 50 & 8.5 & 99 & 29 & 3 & 50 & 7 & 100 \\
\hline 12 & 1 & 60 & 8.5 & 99 & 30 & 3 & 60 & 7 & 100 \\
\hline 13 & 2 & 10 & 7 & 97 & 31 & 3 & 10 & 8.5 & 97 \\
\hline 14 & 2 & 20 & 7 & 98 & 32 & 3 & 20 & 8.5 & 98 \\
\hline 15 & 2 & 30 & 7 & 99 & 33 & 3 & 30 & 8.5 & 99 \\
\hline 16 & 2 & 40 & 7 & 99 & 34 & 3 & 40 & 8.5 & 99 \\
\hline 17 & 2 & 50 & 7 & 100 & 35 & 3 & 50 & 8.5 & 99 \\
\hline 18 & 2 & 60 & 7 & 100 & 36 & 3 & 60 & 8.5 & 100 \\
\hline
\end{tabular}
level of $\alpha=0.05$.

Table 3. Experimental design with Escherichia coli percent removal as response variable

Table 4. Chart of Escherichia coli ANOVA

\begin{tabular}{|cccccc|}
\hline Source of variation & Sum of squares & DF & MS & F-value & P-value \\
\hline $\boldsymbol{x}_{\mathbf{1}}:$ Amperage (A) & 2.66667 & 1 & 2.66667 & 21.82 & 0.0001 \\
$\boldsymbol{x}_{\mathbf{2}}$ : Time (min) & 34.8595 & 1 & 34.8595 & 285.21 & 0.0000 \\
$\boldsymbol{x}_{\mathbf{3}}: \mathrm{pH}$ & 3.36111 & 1 & 3.36111 & 27.50 & 0.0000 \\
$\boldsymbol{x}_{\mathbf{1}}^{2}$ & 0.0555556 & 1 & 0.0555556 & 0.45 & 0.5059 \\
$\boldsymbol{x}_{\mathbf{1}} \boldsymbol{x}_{\mathbf{2}}$ & 0.7 & 1 & 0.7 & 5.73 & 0.0239 \\
$\boldsymbol{x}_{\mathbf{1}} \boldsymbol{x}_{\mathbf{3}}$ & 0.0 & 1 & 0 & 0.00 & 1.0000 \\
$\boldsymbol{x}_{\mathbf{2}}^{\mathbf{2}}$ & 1.34127 & 1 & 1.34127 & 10.97 & 0.0026 \\
$\boldsymbol{x}_{\mathbf{2}} \boldsymbol{x}_{\mathbf{3}}$ & 0.0214286 & 1 & 0.0214286 & 0.6787 & 0.6787 \\
Total error & 3.3 & 27 & 0.122222 & & \\
Total (corr.) & 46.3056 & 35 & & & \\
\hline$R^{2}=92.8734$ \% Adj $R^{2}=90.7618 \%$ & & & & & \\
\end{tabular}




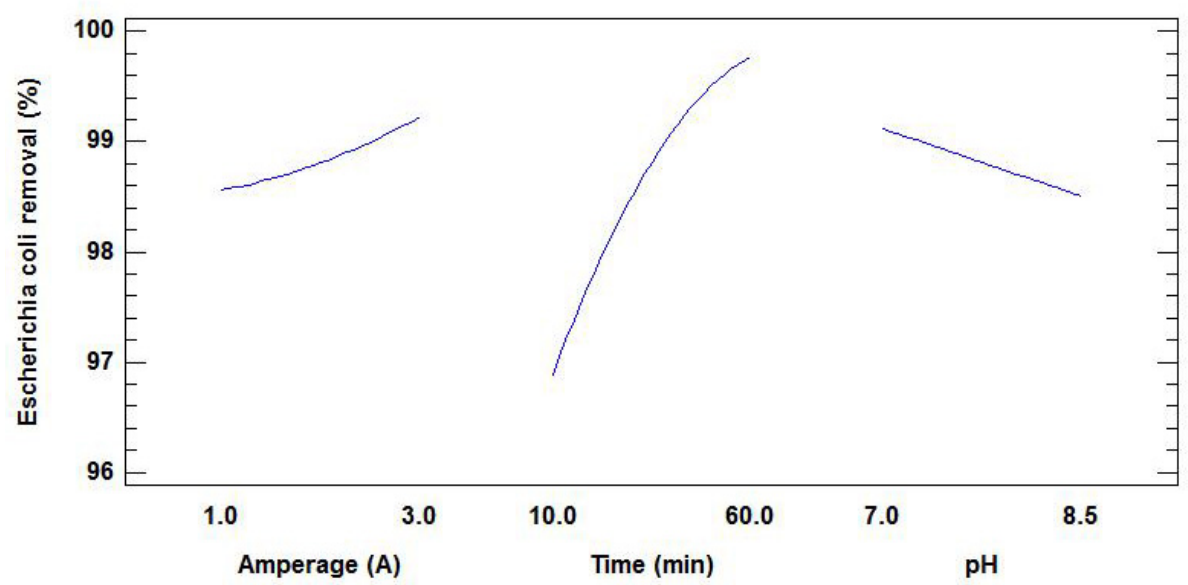

Figure 7. Graph of main effects on the removal of Escherichia coli

a)

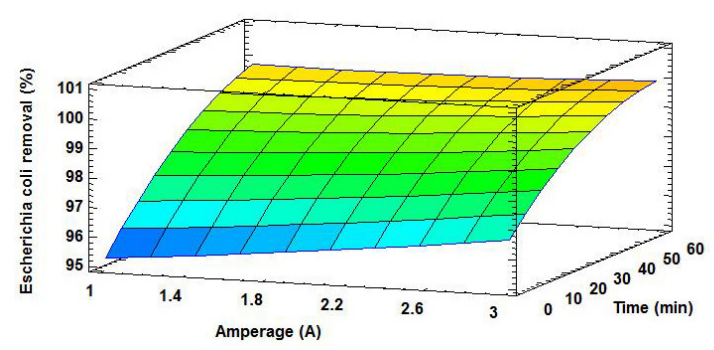

Escherichia coli removal (\%)

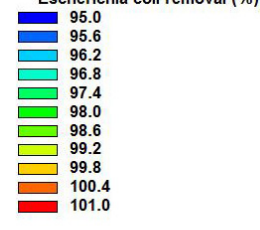

b)

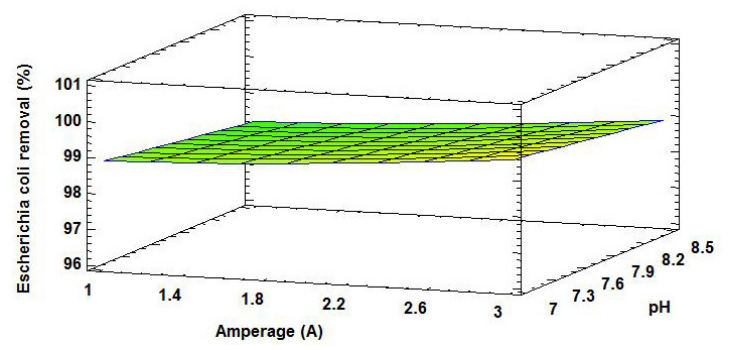

Escherichia coli removal (\%)

c)
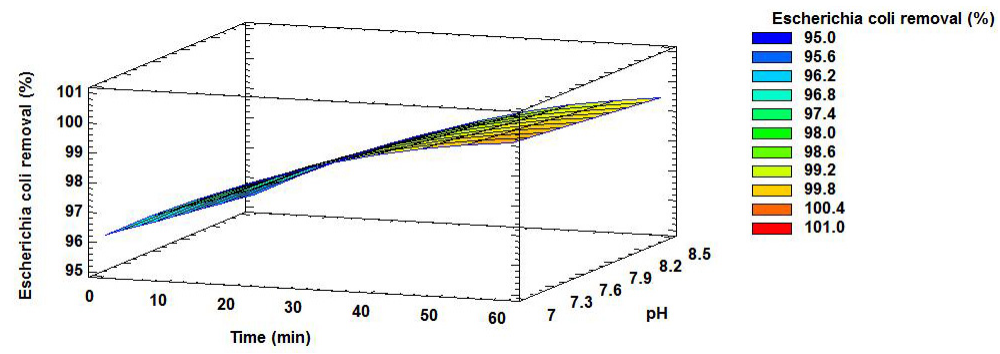

Figure 8. Three-dimensional response surface graphs for Escherichia coli percent removal: (a) amperage and time; (b) amperage and $\mathrm{pH}$; and (c) time and $\mathrm{pH}$

Figure 8 presents the response surface graphs, showing $E$. coli percent removal variation according to amperage, time, and $\mathrm{pH}$.

\section{CONCLUSIONS}

The proposed experimental design indicated that the three variables, namely amperage, time, and $\mathrm{pH}$, significantly affect the response variable
E. coli percent removal. Using this design, a regression coefficient $\left(\mathrm{R}^{2}\right)$ of 0.9287 was obtained, which means that the proposed statistical model explained $92.87 \%$ of the variation in E. coli percent removal, thereby representing a good model fit. The highest $E$. coli percent removal achieved was $99.9 \%$ at a neutral $\mathrm{pH}$ of 7 , amperage of $3 \mathrm{~A}$, and treatment time of $60 \mathrm{~min}$. However, similar values of $99 \%$ were also achieved at the natural wastewater $\mathrm{pH}$ of 8.5 . With regards to the 
treatment time, after 20 min of treatment, $98 \%$ E. coli percent removal was achieved at natural $\mathrm{pH}$ values, whereas a similar value of $99 \%$ was achieved at a $\mathrm{pH}$ of 7 , during which a large quantity of suspended solids and organic matter present in the domestic wastewater are removed. Although the statistical analyses indicated that manipulating $\mathrm{pH}$ to neutrality improved the efficiency, it was not substantial enough to warrant implementation of manipulating $\mathrm{pH}$ in the treatment plant.

In this study, it was clarified that electrocoagulation removes a large percentage of pathogenic microorganisms, such as E. coli, from domestic wastewater. The removal of pathogenic microorganisms in the primary electrocoagulation reactor is superior to traditional biological processes such as activated sludge, which can typically remove $60 \%-80 \%$ of pathogens. This will substantially reduce the use of chlorine during the final treatment stage (disinfection), thereby preventing the discharge of water with high chlorine concentrations.

\section{Acknowledgements}

We thank the Scientific Research Institute of the University of Lima, which promoted the development of this project, and the Wastewater and Hazardous Residues Treatment Research Center of the National Engineering University (Citrar-UNI).

\section{REFERENCES}

1. Ángel G.P. 2015. Desarrollo de un sistema para la desinfección de agua de consumo mediante tratamiento electroquímico. Universidad, Ciencia y Tecnología, 19 (75), 75-81.

2. Attour A., Touati M., Tlili M., Ben Amor M., Lapicque F., Leclerc J-P. 2014. Influence of operating parameters on phosphate removal from water by electrocoagulation using aluminum electrodes, Separation and Purification Technology, 123, 124-129. doi.org/10.1016/j.seppur.2013.12.030.

3. Bouamra F., Drouiche N., Ahmed D.S., Lounici H. 2012. Treatment of Water Loaded With Orthophosphate by Electrocoagulation. Procedia Eng, 33, 155-162. DOI: 10.1016/j.proeng.2012.01.1188.

4. Boudjema N., Drouiche N., Abdi N., Grib H., Lounici H., Pauss A. \& Mameri N. 2014. Treatment of Oued El Harrach river water by electrocoagulation noting the effect of the electric field on microorganisms. Journal of the Taiwan Institute of Chemical Engineers, 45(4), 1564-1570. doi: 10.1016/j. jtice.2013.10.006.

5. Can B.Z., Boncukcuoglu R., Yilmaz A.E., Fil B.A. 2014. Effect of some operational parameters on the arsenic removal by electrocoagulation using iron electrodes. Journal Environment Health Sciences Engineering, 12, 2. doi: 10.1186/2052-336X-12-95.

6. Can O.T. 2014. COD removal from fruit-juice production wastewater by electrooxidation electrocoagulation and electro-Fenton process. Desalination and Water Treatment, 52 (1-3), 65-73. doi.org/10. 1080/19443994.2013.781545.

7. Castro-Ríos K., Taborda-Ocampo G. \& TorresPalma R. 2014. Experimental Design to Measure Escherichia coli Removal in Water Through Electrocoagulation. International Journal of Electrochemical Science, 9, 610-617.

8. Chen G. 2004. Electrochemical technologies in wastewater treatment. Separation and Purification Technology, 38(1), 11-41. Recuperation de http://www.sciencedirect. com/science/article/pii/ S1383586603002636.

9. Chopra A.K. \& Sharma A.K. 2014. Disinfection of Biologically Treated Municipal Wastewater using Electrochemical Process, Separation Science and Technology, 49 (17), 2613-2619. DOI: 10.1080/01496395.2014.937815.

10. Ghernaout D., Bides A., Kellil A. \& Ghernaout B. 2008. Application of electrocoagulation in Escherichia coli culture and two surface waters. Desalination, 219, 118-125. doi:10.1016/j.desal.2007.05.010.

11. Hakizimana J.P., Gourich B., Chafi M., Stiriba Y., Vial C., Drogui P., Naja J. 2017. Electrocoagulation process in water treatment: a review of electrocoagulation modeling approaches. Desalination, 404, 1-21. doi.org/10.1016/j.desal.2016.10.011.

12. Holt P., Barton G., Mitchell C. 2005. The future for electrocoagulation as a localized water treatment technology. Chemosphere, 59, 355-367. http:// dx.doi.org/10.1016/j.chemosphere.2004.10.023.

13. Khandegar V., Saroha A.K. 2013. Electrocoagulation for the treatment of textile industry effluent- A review. J. Environ. Manag, 128, 949-963. https:// doi.org/10.1016/j.jenvman.2013.06.043.

14. Mollah M., Morkovsky P., Gomes J., Kesmez M., Parga J. \& Cocke D. 2004. Fundamentals, present and future perspectives of electrocoagulation. Journal of Hazardous Materials, 114 (1-3), 199-210. https://doi.org/10.1016/j.jhazmat.2004.08.009.

15. Mouedhen G., Feki M., Wery M.P., Ayedi H.F. 2008. Behavior of aluminum electrodes in electrocoagulation process, Hazard J., Mater, 150, 124-135. doi.org/10.1016/j.jhazmat.2007.04.090.

16. Piña M., Martín A., González C., Prieto F., Guevara A. \& García J. 2011. Revisión de variables de 
diseño y condiciones de operación en la electrocoagulación. Revista Mexicana de Ingeniería Química, 10(2), 257-271. Recuperado de http:/www. scielo.org.mx/scielo.php?script=sci_arttext\&pid= S1665-27382011000200010.

17. Ricordel C., Miramon C., Hadjiev D., Darchen A. 2013. Investigations of the mechanism and efficiency of bacteria abatement during electrocoagulation using aluminum electrode. Desalination and Water Treatment, 1, 1-10. doi.org/10.1080/194439 94.2013.807474.

18. Silva B.H.L., Melo M.A.B. 2015. Trihalometanos em Água Potável e Riscos de Câncer: Simulação Usando Potencial de Interação e Transformações de Bäcklund. Quím. Nova, São Paulo, 38 (3), 309-315.

19. Yehya T., Chafi M., Balla W., Vial C., Esadki A., Gourich B. 2014. Experimental analysis and modeling of denitrification using electrocoagulation process. Separation and purification Technology, 132, 644-654. doi.org/10.1016/j.seppur.2014.05.022.

20. Zimmermann U., Schulz J., Pleat G. 1973. Transcellular ion flow in Escherichia coli B and electrical sizing of bacterias. Biochips J, 13(10), 1005-1013. https://doi.org/10.1016/S0006-3495(73)86041-2. 